\title{
Immunohistochemical Detection of BMP-2 and BMP-4 in the Developing Neural Tube and Spinal Cord of Human Embryos
}

\author{
Detección Inmunohistoquímica de BMP-2 y BMP-4 en el \\ Desarrollo del Tubo Neural y Médula Espinal del Embrión Humano
}

Namm, Aimar ${ }^{*, * * ;}$ Arend, Andres*; Aunapuu, Marina ${ }^{*, * *}$

NAMM, A.; AREND, A. \& AUNAPUU, M. Immunohistochemical detection of BMP-2 and BMP-4 in the developing neural tube and spinal cord of human embryos. Int. J. Morphol., 31(2):473-479, 2013.

SUMMARY: The role of bone morphogenetic proteins (BMP-s) in the development of the nervous system has been widely studied on avian and rodent embryos. Human embryos have rarely been available for detection of BMP expression. In this study 39 human embryos of Carnegie stages (CS) 10-20 were investigated. The embryos were fixed in paraformaldehyde, embedded in paraffin and sectioned serially in transverse direction. BMP-2 and BMP-4 protein expression in the developing neural tube and the caudal spinal cord was determined by immunohistochemistry. Our data show that BMP-s tend to be more expressed in the neural tube in earlier stages; in particular, BMP-4 staining was found to be higher at CS10 compared to CS20. More detailed analysis was performed on embryos of CS14-18. Stronger BMP-2 and BMP-4 expression was found in the dorsal part than in the ventral part of the spinal cord. No differences were seen in the staining intensity of BMP-s in the spinal ganglia. Interestingly, in neural crest cells BMP-2 staining was stronger at CS16 and CS18 as compared to CS14, while no differences were found in BMP-4 staining. On the other hand, in the non-neural ectoderm BMP-4 staining was found to be stronger at CS16 than at CS14, while no differences were seen for BMP-2. In conclusion, expression of BMP-s in the developing neural tube and spinal cord of human embryos is generally in accordance with the findings made in rodents and birds.

KEY WORDS: Neural tube; Human embryo; BMP-2, BMP-4; Immunohistochemistry.

\section{INTRODUCTION}

Several families of signaling molecules have been implicated in the control of neural tube patterning including bone morphogenetic proteins (BMP-s). BMP-s, members of transforming growth factor beta (TGF-b) superfamily, play important roles in multiple biological events (Chen et al., 2004; Thawani et al., 2010). Although BMP-s were originally identified by an ability to induce the formation of bone and cartilage, they have been implicated in multiple events during the formation of the nervous system, including neural induction of the neural tube, regionalization of the brain and spinal cord, eye development, and lineage determination in the peripheral nervous system (Hogan, 1996; Timmer et al., 2002).

The central nervous system (CNS) is highly regionalized along both its anterior-posterior and dorsalventral axes (Lupo et al., 2006). During the embryonic development of the nervous system, the most anterior end of the neural tube gives rise to the forebrain, while more posterior regions form the midbrain, the hindbrain and the spinal cord. Many experiments have been made on mice, rats and chickens to find evidence that BMP-2 and BMP-4 are implicated in the patterning of all parts in the developing brain (Jones et al., 1999; Ybot-Gonzales et al., 2007; Hu et al., 2004). The spinal cord is a well-characterized region of the CNS, and BMP activity has been shown to regulate dorsal-ventral patterning of the vertebrate spinal cord (Tucker et al., 2008; Wilson and Maden, 2005). Patterning information along the dorsal-ventral axis of the neural tube can be specified by two processes: the assignment of regional identity and the division of these regions into discrete domains of gene expression (Timmer et al., 2002). Distinct neuronal subtypes are topologically positioned in the spinal cord, and this organization of cells reflects the function of individual neurons. The neurons that process and relay sensory input reside in the dorsal half of the spinal cord, whereas the neurons that participate in motor output are

\footnotetext{
* Department of Anatomy, University of Tartu, Ravila 19, 50411 Tartu, Estonia.

** Institute of Veterinary Medicine and Animal Sciences, Estonian University of Life Sciences, Fr. Kreutzwaldi 62, Tartu, Estonia.
} 
localized ventrally. The appearance of distinct cell types at defined positions in the spinal cord is dependent on inductive signaling pathways. The allocation of the cell fate in the spinal cord, as in other regions of the CNS, depends on two signaling systems that are activated together with the more basic program of neural induction (Jessell, 2000). The gradient of sonic hedgehog $(\mathrm{SHH})$ patterns the ventral spinal neural tube and defines ventral neuronal differentiation, and at the same time BMP activity regulates the dorsal patterning of the spinal cord (Briscoe \& Ericson, 1999; Briscoe \& Ericson, 2001; Dessaud et al., 2008). In addition, BMP-2, BMP-4 and other growth factors are expressed in the nonneural ectoderm, the roof plate and the neural crest of the developing CNS, specifying the dorsal neuronal fates. There are evidences which demonstrate that dorsalization of the spinal cord is likely to result from signals that originate from the non-neural ectoderm as well as neural crest cells ( $\mathrm{Hu}$ et al., 2004; Chizhikov and Millen, 2005; Baker and BronnerFraser, 1997). Additional signals involving members of the Wnt and fibroblast growth factor (FGF) families may also contribute to the proliferation and differentiation of dorsal neuronal cell types (Lee \& Jessell, 1999; Ille et al., 2007). After the reports on the role of BMPs in patterning of the nervous system in the mouse appeared, it has been widely accepted that a similar pattern may be valid for the human. Although the neural tube formation is usually described as a self-evident process, the dorsal-ventral patterning in human embryos has actually not been examined in detail because the human embryo specimens at these developmental stages have only rarely been available. In the present study, 39 externally normal human embryos at Carnegie stages (CS) 10 to 20 were employed, and BMP-2 and BMP-4 protein expression was examined in the developing neural tube.

\section{MATERIAL AND METHOD}

Obtaining embryos and section preparation. Thirty-nine human embryos of Carnegie stages (CS) 10-20 were obtained by medical abortions. The study was approved by the Ethics Review Committee on Human Research of the University of Tartu (no 183/M-40 issued 29.06.2009). The embryos were fixed in $4 \%$ paraformaldehyde and embedded in paraffin according to standard methods. Tissue blocks were serially cut in transversal direction and mounted on glass slides.

Embryos were classified by Carnegie stages (O'Rahilly and Müller, 1987). The developmental stages and the number of embryos used in this study were as follows: stage 10 (4), stage 11 (3), stage 12 (3), stage 14 (11), stage 16 (7), stage 18 (7), and stage 20 (4). According to Carnegie stages, stage 10 corresponds approximately to $22-23$ days of development, stage 11 to $23-26$ days, stage 12 to $26-30$ days, stage 14 to $31-35$ days, stage 16 to $37-42$ days, stage 18 to $44-48$ days, and stage 20 to $51-53$ days.

Immunohistochemistry. Three- $\mu \mathrm{m}$ thick paraffin sections mounted on poly-L-lysine coated slides were deparaffinized and rehydrated. Peroxidase activity was removed by $0.6 \%$ $\mathrm{H}_{2} \mathrm{O}_{2}$ in methanol (Merck, Darmstadt, Germany). Then the sections were washed in tap water and in PBS $(\mathrm{pH}=7.4)$ for 10 min, treated with normal $1.5 \%$ goat serum (Gibco, Invitrogen Corporation, USA) for $20 \mathrm{~min}$ at room temperature and incubated with the first antibody: BMP-2 (Abcam, Cambridge, UK, diluted 1:250); BMP-4 (Abcam, Cambridge, UK, diluted 1:100) overnight at $4^{\circ} \mathrm{C}$. The next day, the sections were washed in PBS and incubated with the secondary antibody (VECTASTAIN ABC Universal Kit, Burlingame, USA) for $30 \mathrm{~min}$ at room temperature. Peroxidatic activity was detected with DAB (Vector, Burlingame, USA). Sections were counterstained with hematoxylin. BMP-2 and BMP-4 labeling was expressed by a subjective scale ranging from 0 to $3(0-$ no staining, 1 - weak staining, 2 - moderate staining, 3 - strong staining). Immunohistochemistry negative controls were performed by omitting the primary antibody. The results were estimated by two independent observers; the mean of estimations was calculated and used for statistical analysis. The data were analyzed by Kruskal-Wallis test (nonparametric ANOVA). The level of significance was set at $p<0.05$.

\section{RESULTS}

Both growth factors - BMP-2 and BMP-4 - were expressed in the developing central nervous system - the neural tube and the caudal end of the spinal cord. The immunohistochemical staining intensity of BMP-2 and BMP-4 in the developing neural tube was detected in CS1020. As seen in Table I, BMP-2 signal was stronger compared to BMP-4. In the case of both growth factors there was tendency for expression to decline in the later stages of development; a significant difference was noted in BMP-4 protein expression in CS10 vs CS20 (Table I).

A more detailed expression pattern of BMP-2 and BMP-4 was studied in CS14, CS16 and CS18 where the number of the studied embryos was larger. Expression of these growth factors in the developing spinal cord, in the spinal ganglia, in the neural crest cells and in the non-neural ectoderm was investigated. As seen in Table II, BMP-2 and BMP-4 staining intensity was clearly stronger in the dorsal part compared to the ventral part of the developing spinal cord (Figs. 1 and 2). 
Table I. BMP-2 and BMP-4 expression of developing neural tube of human embryos in CS 10-20.

\begin{tabular}{lcccccrr}
\hline CS & $\begin{array}{c}\text { CS 10 } \\
(\mathrm{n}=4)\end{array}$ & $\begin{array}{c}\text { CS 11 } \\
(\mathrm{n}=3)\end{array}$ & $\begin{array}{c}\text { CS } 12 \\
(\mathrm{n}=3)\end{array}$ & $\begin{array}{c}\text { CS 14 } \\
(\mathrm{n}=11)\end{array}$ & $\begin{array}{c}\text { CS 16 } \\
(\mathrm{n}=7)\end{array}$ & $\begin{array}{c}\text { CS 18 } \\
(\mathrm{n}=7)\end{array}$ & $\begin{array}{r}\text { CS 20 } \\
(\mathrm{n}=4)\end{array}$ \\
\hline BMP-2 & $2.2 \pm 0.04$ & $2.0 \pm 0.03$ & $1.8 \pm 0.16$ & $1.8 \pm 0.06$ & $2.0 \pm 0.06$ & $1.9 \pm 0.04$ & $1.9 \pm 0.08$ \\
BMP-4 & $1.5 \pm 0.06^{\mathrm{n}}$ & $1.0 \pm 0.10$ & $0.8 \pm 0.05$ & $0.9 \pm 0.05$ & $0.9 \pm 0.05$ & $0.8 \pm 0.06$ & $0.6 \pm 0.09 \mathrm{n}$ \\
\hline
\end{tabular}

BMP-2 and BMP-4 expression in the developing neural tube of human embryos at different Carnegie Stages (CS 10-20). Immunostaining intensity was graded from weak (1) to strong (3); the data are presented as mean \pm SEM. Significant differences $(\mathrm{P}<0.05)$ in staining intensity between groups are indicated with the same letter.
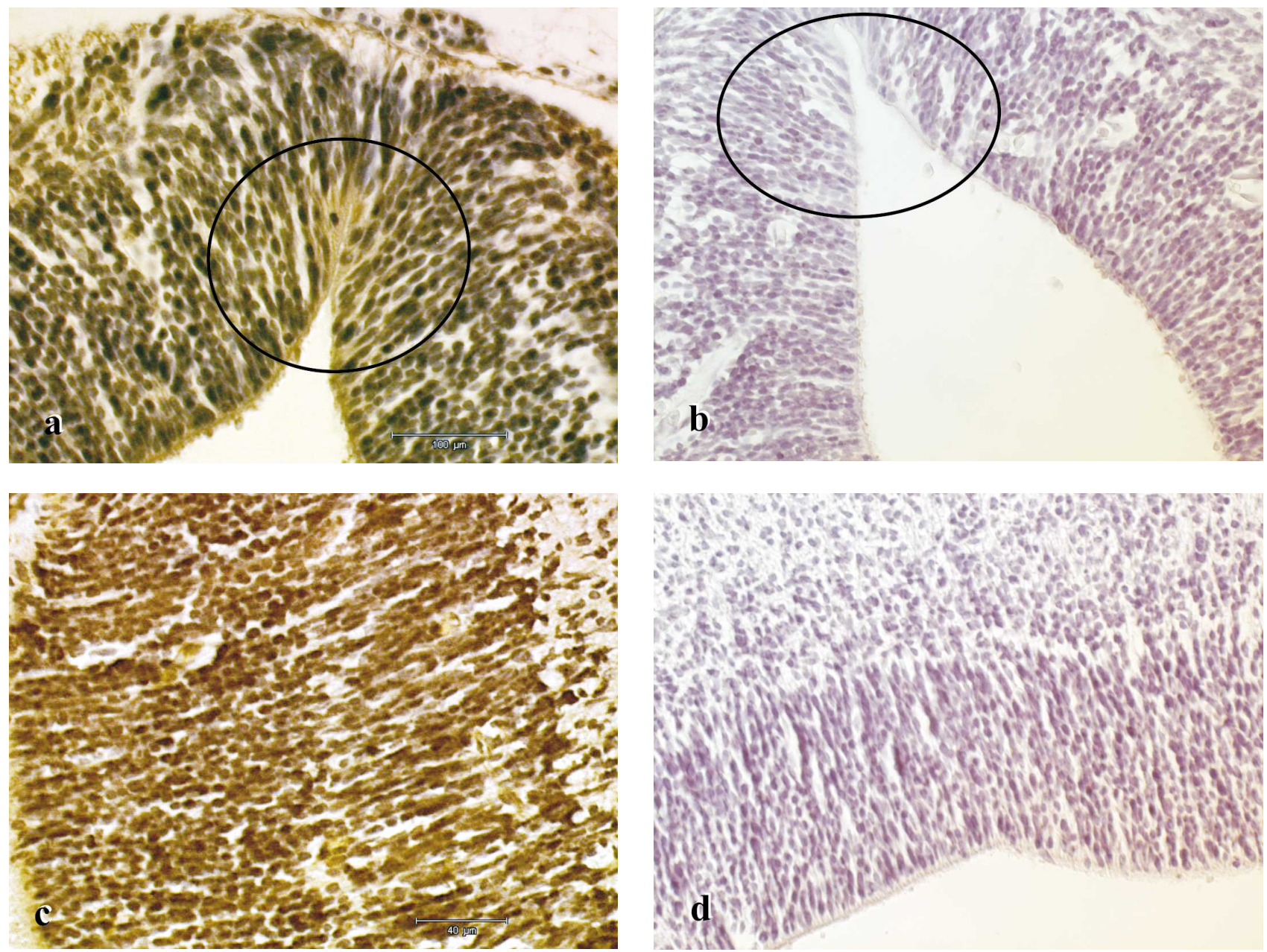

Fig. 1. Transverse sections through the spinal cord of the human embryo of CS18. a.Strong immunohistochemical expression of BMP-4 in the roof plate (encircled area); b. Negative control, no staining in the roof plate (encircled area); c. Strong expression of BMP-2 in the alar plate; d. Negative control, no staining in the alar plate.

At the end of the 5th week of development (CS14), three zones could be distinguished in the wall of the spinal cord: the neuroepithelial layer, the mantle layer, and the marginal layer. Significant expression of BMP-2 was detected in the neuroepithelial layer in CS16-18. Furthermore, expression of both BMP-2 and BMP-4 was found to be at a notable level in the mantel and marginal layer of the developing spinal cord. As a result of continuous addition of neuroblasts to the mantel layer, each side in the wall of the spinal cord shows ventral (basal plates) and dorsal (alar plates) thickening. The right and left alar plates are connected over the central canal by a thin roof plate, and two basal plates are connected ventrally by a floor plate. Our study showed remarkable level expressions of BMP-2 and BMP-4 in the roof and alar plates of the spinal cord in CS14-18 (Fig. 1). We also noticed expressions of BMP-2 and BMP-4 in the floor and basal plates of the spinal cord in CS14-18, but expressions of BMP-s were found to be less intensive compared to expressions of BMP-s in the roof and alar plates. 
No differences in staining intensity were found in spinal ganglia, although the BMP-4 signal was weaker compared to BMP-2 (Table II).
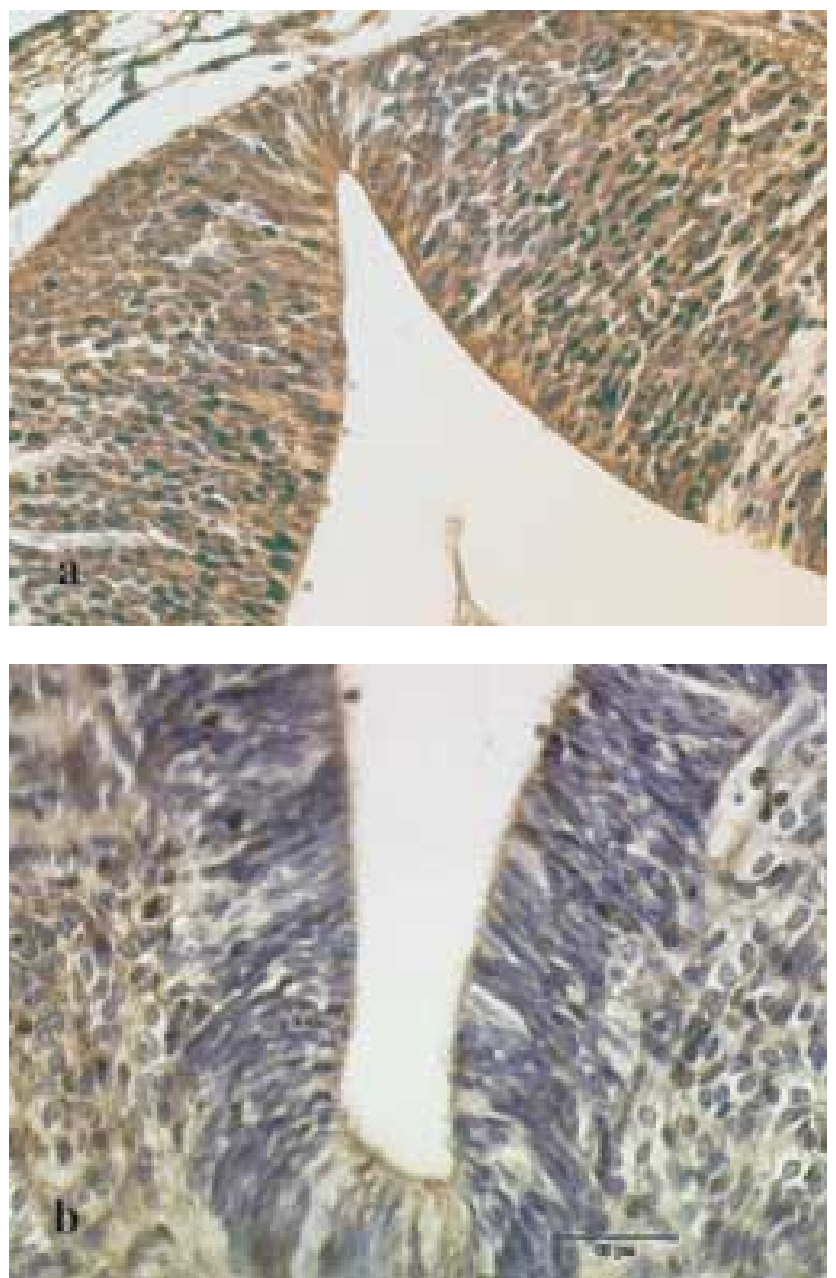

Fig. 2. Transverse sections through the spinal cord of the human embryo of CS18. a. Strong immunohistochemical expression of BMP-2 in the dorsal part; $b$. Weak exprerssion of BMP-2 in the ventral part.
In neural crest cells, BMP-2 staining was stronger in CS16 and CS18, but moderate in CS14 (Table II). On the other hand, BMP-4 protein expression did not differ between CS14, 16 and 18 (Table II).

In non-neural ectoderm, BMP-2 staining was similar in CS14, 16 and 18, but BMP-4 staining was lower in CS14 and stronger in CS16 (Table II).

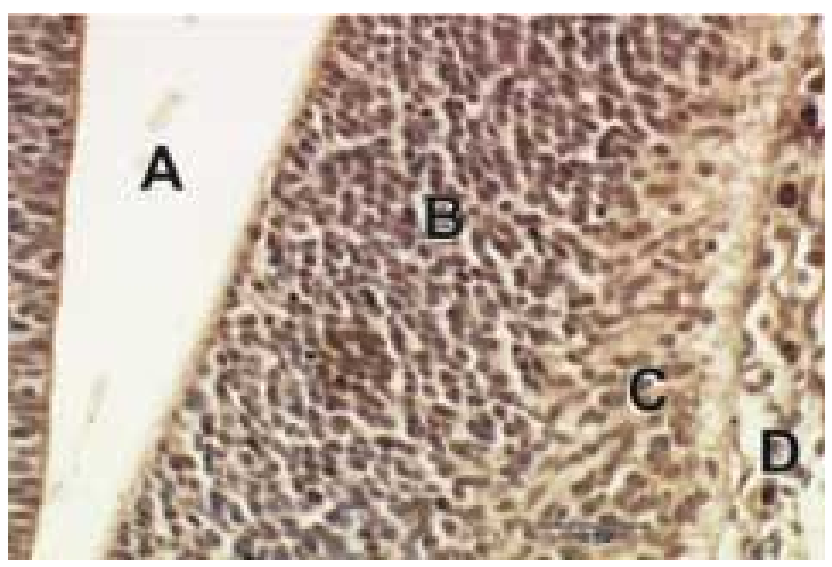

Fig. 3. Transverse section through the spinal cord of the human embryo of CS16. A - Central canal of the spinal cord. Expression of BMP-2 in the neuroepithelial layer (B), mantle layer (C), and marginal layer (D).

\section{DISCUSSION}

The results of our study on BMP-2 and BMP-4 protein expression in the human neural tube and the caudal part of the spinal cord are generally in accordance with the data obtained from animal and chick experiments (Timmer et al., 2002), thus supporting the idea of BMP-s as the key regulators in the differentiation and formation of the neural tissue. In this study we found the signal of BMPs to be

Table II. Expression of BMP-2 and BMP-4 in the spinal cord, spinal ganglia, neural crest cells and non-neural ectoderm of the human embryos.

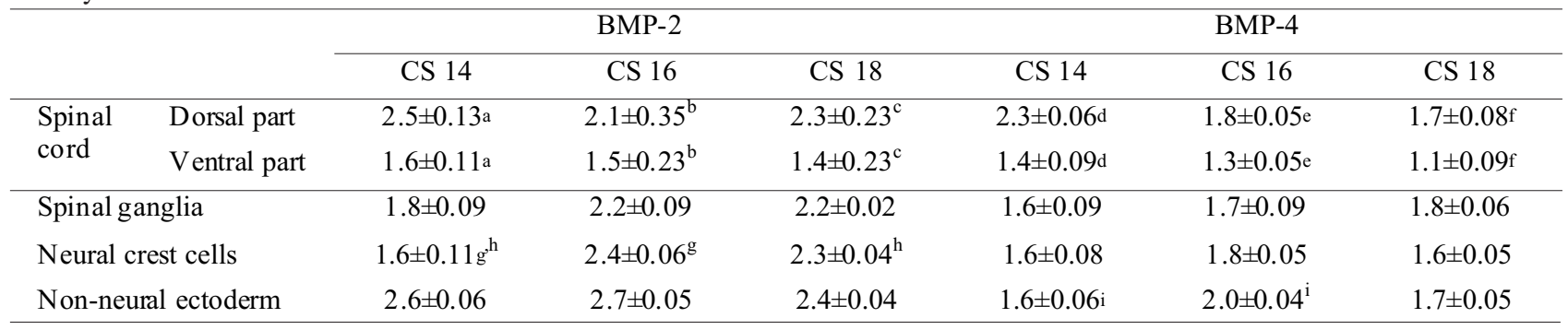

BMP-2 and BMP-4 expression in the developing spinal cord, spinal ganglia and neural crest cells of human embryos at different Carnegie Stages (CS14, n=11; CS16, n=7; CS18, n=7). Immunostaining intensity was graded from weak (1) to strong (3); the data are presented as mean \pm SEM. Significant differences $(\mathrm{P}<0.05)$ in staining intensity between groups are indicated with the same letter. 
stronger in earlier stages of development of the neural tube compared to later stages. In particular, BMP-4 staining was found to be stronger in CS10 than in CS20 (Table I). This finding seems to support the idea that the roles of BMP-s are the most significant when the neural tube has just closed and the formation of the neural tube begins (Ulloa and Briscoe, 2007).

The early spinal cord has a relatively straightforward anatomy compared to more rostral CNS regions. Chizhikov and Millen's works have demonstrated that the organization of the spinal cord is highly dependent on the roof plate signaling activity. As the caudal neural tube closes, the roof plate progenitors differentiate into mature roof plate cells, which occupy the dorsal midline region and act as a dorsal midline organizing center controlling numerous aspects of dorsal spinal cord development (Chizhikov \& Millen, 2004). The first evidence of the role of the roof plate in dorsal spinal cord patterning came from chick and mouse studies. BMP2 and BMP-4 were expressed in the roof plate during neural tube development at the time of dorsal interneuron formation in both mouse and chick (Lee et al., 1998; Liem et al., 2000). In our study BMP protein expression was detected in the developing spinal cord in human embryos where relatively strong BMP-2 and BMP-4 signaling in the roof plate and alar plate cells of the human developing spinal cord of CS1418 embryos was determined, while the signal of BMP-s in the ventral parts was clearly weaker (Table II, Fig. 2). Thus, these findings support the theory that BMP-s play an important role in the proliferation and patterning in the dorsal part of the developing spinal cord of human embryos. However, there are other signals like $\mathrm{SHH}$, members of the Wnt and FGF families, which beside of BMPs may also contribute to the proliferation and differentiation of dorsal neuronal cell types (Lee \& Jessell, 1999; Ille et al., 2007). The wall of the recently closed neural tube consists of neuroepithelial cells which divide rapidly, producing more and more neuroepithelial cells which finally constitute the neuroepithelial layer. The neuroepithelial cells begin to give rise to another cell type - neuroblasts, which form the mantle layer, a zone around the neuroepithelial layer (Sadler, 2005). The outermost layer of the developing spinal cord, the marginal layer, contains nerve fibers emerging from neuroblasts in the mantel layer. Our findings support the role of BMPs in the control of regional specification and morphogenesis of neuronal cells in the developing spinal cord of human embryos, as significant expression of BMP-2 was detected in the neuroepithelial layer of the spinal cord and expression of both BMP-2 and BMP-4 was found to be at notable level in the mantel and marginal layer (Fig. 3).

As the development of the spinal cord proceeds, dorsal interneurons undergo complex cellular migrations generating neuronal circuits that are critical for processing somatosensory information and coordinating motor output. About the end of the fourth week, nerve fibers begin to appear in the marginal layer. The first to develop are the short fibers from the neuroblasts in the mantle zone and the fibers of the dorsal nerve roots which grow from the cells of the spinal ganglia (Sadler, 2004). We can presume that BMP-2 and BMP-4 also have a role in the formation of the spinal ganglia in human embryos, as our data show significant expression of BMP-s in the developing spinal ganglia.

BMP-s also help to define the regions from which a vertebrate-specific population of neural crest cells will be generated (Liu and Niswander, 2005). Most studies on the neural crest cells have been conducted on the avian embryos because of their accessibility and availability of specific markers. The neural crest extends throughout the length of the neural tube and arises at the border between the neuroectoderm and non-neural ectoderm. In our study significant staining of BMP-2 and BMP-4 was found in neural crest cells. Interestingly, BMP-2 protein expression was seen to be higher at CS16 and 18 as compared to CS14, while there were no differences in BMP-4 between CS14, CS16 or CS18 (Table II). Strong expression of BMP-2 was also detected in non-neural ectoderm in CS14, CS16 and CS18, but on the other hand, BMP-4 staining was found to be higher at CS16 as compared to CS14 (Table II). This may demonstrate different regulatory roles of BMP-s at various developmental stages as BMP-s act on concentration-dependent manner (Wilson \& Maden, 2005; Barth et al., 1999).

In conclusion, the study demonstrates that BMP-2 and BMP-4 immunostaning was more intensive in the developing human neural tube in earlier stages, in particular when comparing CS10 and CS20. In concordance with the experiments performed in rodents and chickens, in this study stronger protein expression of BMP-s was seen in the dorsal part and weaker in the ventral part of the human spinal cord. Interestingly, some differences were noted in BMP-2 and BMP-4 protein expression between CS14, CS16 and CS18: more intensive immunohistochemical staining of BMP-2 was seen in neural crest cells of CS16 and CS18 as compared to CS14, while in the non-neural ectoderm BMP-4 protein expression was found to be weaker in CS14 as compared to CS16.

\section{ACKNOWLEDGMENTS}

The help of Dr. A. Sizarov in the process of collecting human embryos is greatly acknowledged. The study was partly funded by the targeted project No 0180012s 11 of the Estonian Ministry of Education and Research. 
NAMM, A.; AREND, A. \& AUNAPUU, M. Detección inmunohistoquímica de BMP-2 y BMP-4 en el desarrollo del tubo neural y médula espinal del embrión humano. Int. J. Morphol., 31(2):449-454, 2013.

RESUMEN:El papel de las proteínas morfogenéticas óseas (BMP-s) ha sido ampliamente estudiado en el desarrollo del sistema nervioso en embriones de aves y roedores. Los embriones humanos rara vez han estado disponibles para la detección de la expresión de BMP. En este estudio se investigaron 39 embriones humanos de los estadios Carnegie (CS) 10-20. Los embriones fueron fijados en paraformaldehído, embebidos en parafina y seccionados en serie en dirección transversal. Se determinó por inmunohistoquímica BMP2 la expresión de la proteína BMP-4 en el tubo neural y en la médula espinal caudal en desarrollo. Nuestros resultados mostraron que la BMP-s tienden a ser más expresadas en el tubo neural en etapas tempranas, en particular, se encontró tinción BMP-4 más alta en comparación con CS10 CS20. Un análisis más detallado se realizó en embriones de CS14-18. En la parte dorsal se observó mayor expresión de BMP-2 y de BMP-4 que en la parte ventral de la médula espinal. No se observaron diferencias en la intensidad de la tinción de BMP-s en los ganglios espinales. Curiosamente, en las células de la cresta neural BMP-2 la tinción fue más fuerte en CS16 y CS18 en comparación con CS14, mientras que no se encontraron diferencias en la tinción de BMP-4. Por otro lado, en el ectodermo no neural se encontró tinción BMP-4 más fuerte en CS16 que en CS14, mientras que no se observaron diferencias para BMP-2. En conclusión, la expresión de BMP-s en el tubo neural en desarrollo y la médula espinal de embriones humanos está generalmente de acuerdo con los hallazgos realizados en roedores y aves.

PALABRAS CLAVE: Tubo neural; Embrión humano; BMP-2; BMP-4; Inmunohistoquímica

\section{REFERENCES}

Baker, C. V. H. \& Bronner-Fraser, M. The origins of the neural crest. Part I: embryonic induction. Mechanisms of Development, 69: 3-11, 1997.

Barth, K. A.; Kihimoto Y.; Rohr, Seydler, K. B. C. \&. Wilson, S. W. Bmp activity establishes a gradient of positional information throughout the entire neural plate. Development, 126:497787, 1999.

Briscoe, J. \& Ericson, J. Specification of neuronal fates in ventral neural tube. Development, 11:43-9, 2001.

Briscoe, J. \& Ericson, J. The specification of neuronal identity by graded sonic hedgehog signaling. Cell \& Developmental biology, 10:353-62, 1999.

Chen, D.; Zhao, M. \& Mundy, G. R. Bone morphogenetic proteins. Growth factors, 22(4):233-41, 2004.

Chizhikov, V. V. \& Millen, K. J. Mechanism of roof plate in vertebrate CNS. Nat. Rev. Neurosci., 5(10):808-12, 2004.

Chizhikov, V.V. \& Millen, K.J. Roof plate-dependent patterning of the vertebrate dorsal central nervous system. Developmental Biol., 277:287-95, 2005.

Dessaud, E.; McMachon A.P. \& Briscoe, J. Pattern formation in the vertebrate neural tube: a sonic hedgehog morphogenregulated transcriptional network. Development, 135:2489-503, 2008.

Hogan, B.L. Bone morphogenetic proteins: multifunctional regulators of vertebrate development. Genes. Dev., 10:158094, 1996.
Hu, Q.; Ueno, N. \& Behringer, R. R. Restriction of BMP-4 activity domains in the developing neural tube of the mouse embryo. EMBO., 5:734-39, 2004.

Ille, F.; Atanasoski, S.; Falk, S.; Ittner, L. M.; Märki, D. \& Sommer, L. Wnt/BMP signal integration regulates the balance between proliferation and differentiation of neuroepithelial cells in the dorsal spinal cord. Dev. Biol., 304(1):394-404, 2007.

Jessell, T. M. Neuronal specification in the spinal cord: inductive signals and transcriptional codes. Genetics, 1:20-9, 2000.

Jones, C. M.; Lyons K. M. \& Hogan, B. L. M. Involvement of bone morphogenetic protein-4 (BMP4) and Vgr-1 in morphogenesis and neurogenesis in the mouse. Development, 111:531-42, 1999.

Lee, K. J. \& Jessell, T. M. The specification of dorsal cell fates in the vertebrate central nervous system. Annu. Rev. Neurosci., 22:261-94, 1999.

Lee, K. J.; Mendelsohn, M. \& Jesell, T. M. Neuronal patterning by BMP-s: a requirement for GDF7 in the generation of a discrete class of commissural interneurons in the mouse spinal cord. Genes \& Development, 12:3394-407, 1998.

Liem, K. F.; Jessell T. H. \& Briscoe, J. Regulation of the neural patterning activity of sonic hedhehog by secreted MBP inhibitors expressed by notochord and somites. Development, 127:4855-66, 2000.

Liu, A. \& Niswander, L. A. Bone morphogenetic protein signaling and vertebrate nervous system development. Neuroscience, 6:945-54, 2005. 
Lupo, G.; Harris W. A. \& Lewis, K. E. Mechanisms of ventral patterning in the vertebrate nervous system. Neuroscience, 7:103-14, 2006.

O’Rahilly, R. \& Müller, F. Developmental stages in human embryos. Carnegie Institution of Washington. Washington, DC. 1987.pp $1-306$.

Sadler, T. W. Embryology of neural tube development. Semin. Med. Genetic., 135C:2-8, 2005.

Sadler, T. W. Langman's medical embryology. $9^{\text {nd }}$ ed. Baltimore, Lippincott Williams \& Wilkins. 2004. pp 433-65.

Thawani, J. P.; Wang A. C.; Than K.D.; Lin C. Y. \& Park, P. Bone morphogenetic proteins and cancer: Review of the literature. Neurosurgery, 66:233-46, 2010.

Timmer, J. R.; Wang C. \& Niswander, L. BMP signaling patterns the dorsal and intermediate neural tube via regulation of homeobox and helix-loop-helix transcription factors. Development, 129:2459-72, 2002.

Tucker, J. A.; Mintzer K. A. \& Mullins, M. C. The BMP signaling gradient patterns dorso - ventral tissues in a temporally progressive manner along the anteroposterior axis. Dev. Cell., 14(1):108-19, 2008

Ulloa, F. \& Briscoe, B. J. Morphogenesis and the control of cell proliferation and patterning in the spinal cord. Cell. Cycle., 6:2640-9, 2007

Wilson, L. \& Maden, M. The mechanisms of dorsoventral patterning in the vertebrate neural tube. Dev. Biol., 282:1-13, 2005 .

Ybot-Gonzales, P.; Gaston-Masseut C.; Girdler G.; Arkell R.; Nicholas D. \& Greene, E. Neural plate morphogenesis during mouse neurulation is regulated by antagonism of Bmp signaling. Development, 134:3203-11, 2007.

\section{Correspondence to: \\ Namm, Aimar \\ Department of Anatomy \\ University of Tartu \\ Ravila 19, 50411 Tartu \\ ESTONIA}

Email: aimar.namm@ut.ee

Tel: +3727374250

Fax: +372 7374252

Received: 12-09-2012

Accepted: 29-01-2013 